\title{
The Impact of Trade Openness and Foreign Direct Investment on Economic Welfare in sub-Saharan Africa
}

\author{
Folasade Bosede Adegboye ${ }^{1}$, Olumide Sunday Adesina ${ }^{2}$, Felicia Omowunmi Olokoyo ${ }^{1}$, Stephen Aanu Ojeka ${ }^{3} \&$ \\ Victoria Abosede Akinjare ${ }^{1}$ \\ ${ }^{1}$ Department of Banking and Finance, College of Management and Social Sciences, Covenant University, Ota, \\ Nigeria \\ ${ }^{2}$ Department of Mathematical Sciences, Redeemer's University, Ede, Nigeria \\ ${ }^{3}$ Department of Accounting, College of Management and Social Sciences, Covenant University, Ota, Nigeria \\ Correspondence: Folasade Bosede Adegboye, Department of Banking and Finance, College of Management and \\ Social Sciences, Covenant University, Ota, Nigeria.
}

Received: August 29, 2020

Accepted: November 21, 2020

Online Published: February 19, 2021

doi:10.5430/ijfr.v12n2p389

URL: https://doi.org/10.5430/ijfr.v12n2p389

\begin{abstract}
The sub-Saharan African region is characterized by a high relative degree of openness to trade. The region is also identified with increased inflows of foreign investments with no significant welfare improvement. Economic development emphasizes that the lack of domestic investment in the developing economies could be boosted by trade openness and inflow of Foreign Direct Investment (FDI) for impactful enhancement of capital formation. In this article, the impact of trade openness and foreign capital inflow on economic welfare was examined on a sub-regional analysis for sub-Saharan Africa. The study also appraised the effect of openness to trade and FDI inflow on the region's economic welfare. The data for 30 countries from 2000 to 2018 were collected and analyzed, with the Generalized Least Square (GLS) technique to fit the model developed. The study showed that openness to trade has a significant impact on economic welfare for all sub-Saharan Africa regions, while FDI is only significant for the Western sub-region. Hence, the study recommends that the government of the countries in the sub-Saharan Africa region should boost trade openness to enhance efficiency in productivity, and improve industrial development.
\end{abstract}

Keywords: economic welfare, foreign direct investment, generalized least square, sub-regional analysis, sub-Saharan Africa, trade openness

\section{Introduction}

For more than four decades, foreign investment in the African region has had an unpredictable trend with a continuous decline from about $\$ 51$ Billion to $\$ 42$ Billion, amounting to a 21 percent fall from 2016 (UNCTAD, 2018). It is expected that openness to trade would invariably encourage the further flow of foreign capital into the region. Sustainable development asserts that the salient deficiency of domestic investment, which characterizes host developing economies, can be enhanced by a steady inflow of FDI to the economy's dominant sectors. It would impact domestic investment and engage domestic investors' progressive involvement by stimulating and enriching the domestic industries (Amoo 2018). This study focuses on trade openness and foreign direct investment, and their economic welfare impact, on a sub-Saharan African regional analysis.

For sub-Saharan Africa, there are excellent prospects as well as dire concerns that are enduring. The region has access to the free trade area with the most extensive ever global range. The incidence of the African Continental Free Trade Area Agreement (AfCFTA) with the availability of excellent market access creates a novel avenue for growth, connecting the possible opportunities of both domestic and human capital (Adegboye, Odularu \& Matthew, 2020). Openness to international trade is associated with economic growth and welfare for developing economies as in sub-Saharan Africa with tendencies of impact deviation depending on the income level or how developed the economy is (Brueckner \& Lederman, 2015; Lumengo \& Emilie, 2019). Openness to trade has also been said to harness external finance's inflow, as both are means of making up for scarce resources in developing economies. Efforts have been made to decrease tariffs globally to make provision for greater access to supplies and enhance the better open trading system. UN (2020) in 2017, reported that the rates of trade weights declined to about 2.2 percent globally, with Africa accruing the highest standards, which, however, still created a wide variance regionally, hence, depicting economic inequality globally. 
In the 1970s and early 1980s, the highest proportion of total FDI in the African region came to West Africa; however, the West African region had a 15 percent decline from $\$ 11$ Billion to $\$ 9.6$ Billion in 2018, in the most implausible manner, since 2006, due to reduction in inflow to certain countries below the usual level of investment. On the other hand, the North African sub-region had received a high proportion of total FDI next to the West African sub-region within the same period. Still, unlike the West African sub-region, it had an increase of 7 percent in 2018 from $\$ 13$ billion to about $\$ 14$ Billion, thereby having a higher proportion than the West African sub-region due to increased investments for several countries in the region. In 2018, there was not much change for the eastern sub-region as the FDI flows stood at $\$ 9$ Billion. The Southern sub-region also had the highest percentage proportion of total FDI in the year 1974, 1997, 2001, and had a whopping value of over 300 percent increase in FDI inflow from \$925 Million in 2017 to $\$ 4.2$ Billion in 2018. Overall, as of 2012, the West African sub-region benefited the highest proportion of total FDI with a percentage of 31.3 percent, followed by the North African sub-region, with 29.1 percent. The proportion of West and North Africa amounted to over 60 percent of total FDI for all African countries. This implies that the two sub-regions had a greater share than the other three sub-regions put together; however, the West African sub-region has currently had an unfortunate decline in the inflow of FDI. Like East Africa, the Central African sub-region in all has also received only a little percentage of total FDI flow into Africa, which remained very static in 2018, at flows of $\$ 8.8$ Billion (UNCTAD, 2012; 2018).

The study by Rao, Tamazian, Singh, \& Vadlamannati (2008) showed that the mechanisms for growth are typically openness to trade, the inflow of foreign capital, a substantial investment, education, growth of human resources, productivity, high savings rate, and macroeconomic stability. The degree of both trade openness and the international flow of capital have increased tangibly in recent years. FDI as a proportion of GDP in sub-Saharan African countries (SSA) rose by more than 85 percent between 1995 and 1997 (Osabuohien \& Efobi, 2014). These flows have been within developed and the underdeveloped regions (Carbonell \& Werner 2018). Also, foreign capital flow to underdeveloped countries results in the "pull" and "push" indicators. The pull factors result from the transformation in policies and several other features opening up to underdeveloped countries. These include easing up of capital accounts, home stock markets, and enormous privatization schedules. The factors originate from business-cycle circumstances and macroeconomic policy amendments in developed countries. From an extensive viewpoint, this latter group of indicators encompasses the increase in institutional investors' significance in developed countries and demographic changes (Prasad, Rogoff, Wei, \& Kose, 2003).

There are propositions, regarding sub-Saharan Africa as well as other middle-income economies in Latin America regarding trade openness, that there is a high incidence of trade growth as a result of the pursuit of openness of trade (Wacziarg \& Welch, 2008; Falvey, Foster, \& Greenaway, 2012; Salinas, Gueye, \& Korbut, 2014; Matthew \& Adegboye, 2014). It was opined that the application of trade in the trade openness context was more topical instead of the limited context of viewing trade as merely export operations (Winters \& Masters, 2013). The study conducted by Winters \& Masters (2013) showed that openness to trade provides a broader interpretation for trade, including exports and the movement of imports of an economy, in a different perspective from earlier studies that measured trade by export operations. Customarily, economic theory says that trade and foreign capital investment are a major catalyst for growth in developing economies. Hence as openness to trade as well as investment flows in from developed to underdeveloped economies, there is a boost in the general economic wellbeing (Geda \& Seid, 2015, Ali \& Xialing, 2017). Specifically, inflow ought to be from countries with greater tangible per capita income, with a minimal return on investment, to those with reasonably lower capital but larger idle investment prospects. The standard is that this capital movement should enhance the underdeveloped countries by availing them access to more significant resources. This could be invested in tangible assets, comprising of machines and infrastructural facilities, which invariably ought to enhance income and employment levels (Alfaro \& Chauvin 2018).

The expectation in line with the standard theory is that flow of capital and trade openness should result in development economically for recipient countries. Thereby countries that are more open to foreign capital flow should invariably develop faster than those with lesser flows. This has been evidenced in the research work of Osabuohien; Efobi \& Gitau (2015), as it is evidenced that inflow of foreign investment through the incidence of MNCs have a tangible impact on the domestic economies. However, this is notably different as countries with lesser flows have been seen to experience faster growth and hence, development than countries that have accessed more flows of foreign capital (Prasad, Rajan \& Subramanian, 2007).

\section{Theoretical Framework and Literature Review}

Most African countries are developing economies. They are beset by various problems such as inadequate infrastructural facilities, low education level of the labour force, corruption, and insufficient income, which also translates to low domestic savings and low domestic investment. The research of Prasad et al. (2007) aimed to examine 
how trade openness and capital flows enhance growth, differently from how it has been done in other studies previously. The standard economic theory was utilized, and the regression method of analysis was espoused. In the examination, 59 underdeveloped economies were arranged during the specified period 1970-2004. The study summed that current accounts of non-industrialized countries are related positively to growth in the long run. Therefore, countries that grew faster depended less on the foreign flow of capital, also a negative relationship for developed countries (Zahonogo 2016).

The perverse trend of developing economies with high growth rates, which attracts lesser FDI net inflow, shows that FDI net inflow does not pursue growth, thereby suggesting that economies that grow quicker perhaps possess enhanced investment avenues. Since openness alludes as a catalyst for economic growth and welfare for developing economies, it could hence, be seen as an avenue to boost economic activities, domestic savings, and investment in the developing regions (Geda \& Seid, 2015; Ali \& Xialing, 2017; Ikpesu, Vincent \& Dakare, 2019; Adegboye, Odularu \& Matthew, 2020). The question hence, of why FDI does not flow to countries with rapid growth and high marginal productivity of capital, could thus be answered by the availability of investment avenues in the economies that welcome them. Underdeveloped economies that depend less on FDI have experienced quicker growth over the years than those that have not. The driver of their growth was indigenous savings that emanated from more profound determinants or originated personally from growth, therefore relating domestic savings to investment and, consequently, higher growth (Adegboye, Ojo \& Oguninola 2016).

The research work of Adegboye (2014) established that FDI has no tangible effect relative to the close-up of the foreign exchange and savings limit in the studied African economies, which is converse to the conjecture stated by Chenery and Strout (1966). The net flow of international capital should increase domestic activities; this will consistently increase income, savings, and progressively eliminate foreign exchange and investment limits. However, trade could boost domestic activities, savings, and investment and, hence, economic welfare for developing economies (Geda \& Seid, 2015; Ali \& Xialing, 2017; Adegboye, Odularu \& Matthew, 2020). On the other hand, it is anticipated that foreign investment inflow into the domestic economy should sustain more welfare. This would result in a decline in the need for external assistance as perceived in previous studies (Workneh \& Francken 2015) and obtainable in other developing regions of the world, most notably in Asia and Latin America.

Eozenou (2008) argues that foreign capital flows were significantly boosted in the late 1980s and 1990s, as it was regarded as a source of probable essential benefits. First, he highlighted that freedom to international financial markets and trade openness was an added source to investment finance, which could result in additional accumulation of capital, particularly in economies with very minimal capacity to save relative to low-income level. Consequently, trade openness in the markets, and foreign capital inflows could result in the greater and efficient allocation of capital by improving market discipline and reinforcing the banking system. All put together, enhanced allocation of capital and improved efficiency allocation are expected to reduce the investment cost, and therefore, advance greater growth, as a required determinant of development.

The African region has been typified with the comparative rise of foreign investment inflows; however, no tangible impact on domestic investment, growth indicators, and development is obviously seen in the sub-regions. This means that foreign capital has not flowed into the economy's right sectors, which could boost output and result in expected growth. It thereby has not been quantifiably beneficial as expected, although; foreign capital inflow is prominent as a major channel for growth in an economy. Economies that have accessed the flow of foreign investment have been said to have developed faster than those that have not (Carbonell \& Werner 2018), in conditions of enhancement in income per capita and improved living standard (Rao et al., 2008). Macroeconomic policies should unambiguously seek to attain and maintain a high growth level and wellbeing, which could be achieved by easing trade activities, engendering an appreciation of domestic savings, and investment activities. This is because of the relationship between increasing returns, probabilities, and the expectations for growth to be maintained. A high growth policy will persuade countries to additional investments in development and research. This will further make higher investments in the dynamic form of innovative capital, rising growth rate, economic efficiency, increasing wages, incomes, and standard of living (Bluestone \& Harrison, 2000).

This should be married with economies that have access to liberalized markets and inflow of foreign investment. They should ensure that macroeconomic policies are put in place, which will dynamically seek to achieve and consequently retain the level of growth in income attained. The capital approach to sustainable development gives emphasis to and guarantees a per capita national wealth that does not wane by preserving the wealth source, which is; reserve generated human capital, public capital, and natural resource capital. Turner (1988) found that the standard such as the best possible (sustainable growth) policy would seek to sustain an adequate growth rate in real income per capita (Alfaro \& 
Chauvin 2018), without a decline in the national asset stock of capital or asset stock of natural resources. The World Commission on Environment and Development (WCED, 1987) believes that sustainable development secures the current generation's requirements without conceding the capability of the upcoming generation in meeting their own needs. This thereby infers to us that as foreign investment is welcomed, enhanced by trade openness, the growth impact must reflect on the domestic level of income per capita. This will consequently be transmitted to enhance domestic investment in the host economy (Carbonell \& Werner 2018), thereby resulting in better welfare that can be retained.

The sustainable Livelihood theory accentuates the sustainability necessity of capital formation and its buildup in the host economies' domestic investment. The significance of domestic investment's effectiveness is consequentially a greater equilibrium level of income per capita, a rise in employment, and twice the gain of increased input of production and linkages for local firms in the domestic sector (Du and Kang 2016). This is achieved via diffusion, which promotes healthy competition and thus the effectiveness of domestic investment ensuing from enhanced trade activities and the flow of foreign funds. The focused involvement in the synergy increases productivity, showing that both liberalized markets and foreign capital inflow left standing on its own may not bring desired growth expectations. Except it engages the domestic sector's productivity to generate required growth anticipations and further boosts economic efficiency. It would consistently result in a stable rise in growth rates and the economic welfare of host economies. According to Mensah (2019), sustainability submits to preserving and improving the enduring productivity resource. It could attain this, with adaptive policies and capabilities to produce and sustain their living means, and improve the welfare of the upcoming generations.

According to Prasad et al. (2007), a direct relationship exists between the surplus of the current account and the country's growth rate. The likely justification is that the correlation shows that enhanced savings from the domestic sector could be established by more profound determinants or engendered by growth itself. Nevertheless, trade and investment could be an explicitly indirect association amid current account and growth. Indeed, it shows that the positive relationship found is quantifiably enhanced by domestic savings. The increase in domestic savings is expected to strengthen the substantial increase in domestic investment. Then, the domestic economy gradually develops to a decrease in foreign financing reliance (Chenery \& Strout, 1966; Workneh \& Francken 2015).

\section{Research Methods}

Based on the standard economic theory, developing economies are globally beset by various problems; inadequate infrastructural facilities, low education of labor force, corruption, and insufficient income, which also translates to low domestic savings and low domestic investment. The degree of openness and the inflow of foreign investment are expected to boost low domestic savings and investment to enhance development and economic welfare in these economies (Prasad et al., 2007). Hymer (1976) emphasized that underdeveloped countries possess low income per capita. Thus, liberalizing and acquiring foreign finance is essential as indigenous savings are minimal at the initial development stage. As the rate of development advances, the dependence on foreign finance steadily decreases as indigenous savings and domestic investment steadily rises. As expected, thereby results in income growth, development, and improved living standards for developing economies (Buckley 2010).

The model for the research work derives intuition from the empirical study of Adegboye (2014). The study utilized data from the Human Development Index (HDI) and World Development Indicators between (2000-2018).

\subsection{Empirical Model}

A sample of 30 African countries across the Central, Eastern, Southern, and Western sub-regions of Africa was selected based on the data accessibility for the study period. The countries chosen for the Central sub-region are; Angola, Cameroon, Central African Republic, Chad, Democratic Republic of Congo, Equatorial Guinea, and Gabon. In the Eastern sub-region, Ethiopia, Kenya, Madagascar, Malawi, Mauritius, Mozambique, Rwanda, Tanzania, and Uganda. In the Southern sub-region, Botswana, Eswatini, Namibia, South Africa, and Zambia. In the Western sub-region, Benin, Cote d'Ivoire, Gambia, Ghana, Guinea, Mali, Mauritania, Nigeria, and Senegal. Hence, the standard model for the research work is stated in the implicit form as;

$$
\begin{gathered}
H D I=f(\text { TRDOPEN,FDI,DOMINV,INFR, } L, R O I,) \\
\left.H D I=\beta_{0}+\beta_{1} * \log _{(\mathrm{TRDOPEN})}+\beta_{2} * \text { FDI }+\beta_{3} * \log (\mathrm{DOMINV})+\beta_{4} * \log (\text { INFR })\right) \\
+\beta_{5} * \mathrm{~L}+\beta_{6} * \log (\text { ROI }
\end{gathered}
$$

Where: HDI denotes Human Development Index representing economic welfare, TRDOPEN means trade openness; FDI stands for foreign direct investment; DOMINV is Domestic investments; INFR is infrastructure; L is active labour force; ROI stands for rate of return on investment; and $\varepsilon$ which is the error term. 
$\beta_{0}$ is the constant term, $\beta_{1}, \beta_{2}, \beta_{3}, \beta_{4}, \beta_{5}, \beta_{6}$, are the coefficients of the explanatory variable. Both ' $i$ ' and ' $t$ ' denote entities and time, respectively. According to sub-regions earlier stated for this study, entities indicate the 30 SSA countries, while time indicates the research period (2000-2018). The 'Apriori' expectation for the research work is provided as $\beta_{1}>0, \beta_{2}>0, \beta_{3}>0, \beta_{4}>0, \beta_{5}>0, \beta_{6}>0$. It infers that the explanatory variables are expected to have a positive impact on economic welfare.

The variables used in specifying the model are derived from two sources: the Human Development Index (HDR, 2017) and the World Development Indicators (WDI, 2017). For the estimation of the model specified, the research work utilized the Generalized Least Squares model.

\subsection{Generalized Least Squares (GLS)}

The GLS is utilized for estimating parameters in a linear model. It is employed in a situation where there is a significant correlation in the residuals. If such a correlation occurs, the ordinary least square method is considered unsuitable for fitting such a data set because it can result in misleading inferences. The GLS was first introduced by Aitken (1934). Current literature contains a modification of the GLS, such as the feasible generalized least squares technique (Musau, Waititu \& Wanjoya, 2015). The author fitted panel data using Feasible Generalized Least Square (FGLS) along with robust covariance matrix estimation and draws a comparison between the models.

A linear regression for observed response and covariates for a given set of data $\left\{y_{i}, x_{i j}\right\}, i=1,2, . . n, j=1,2, \ldots, k$. The responses are represented in a vector $\boldsymbol{y}=\left(y_{1} \ldots y_{n}\right)$, and covariates sometimes called predictor value are represented in design matrix $\boldsymbol{X}=\left(\boldsymbol{x}_{1}, \ldots, \boldsymbol{x}^{T}{ }_{1}\right)^{T}$, where $\boldsymbol{x}_{i}=\left(1, x_{2 i}, \ldots, x_{k i}\right)$ represent the vector of $k$ predictor variables for the $i^{\text {th }}$ unit. A GLS is of the form

$$
\boldsymbol{y}=\boldsymbol{X} \beta+\varepsilon
$$

where $\boldsymbol{y}$ is the $n \times 1$ response vector, $\boldsymbol{X}$ is a $n \times p$ matrix, and $\beta$ is $p \times 1$, and $\varepsilon$ is a $n \times 1$ vector of errors. The expectation value of the error term given $\boldsymbol{X}$ is zero, $(\varepsilon \mid \boldsymbol{X})=0,(\varepsilon \mid \boldsymbol{X})=\Psi$, where $\Psi$ is the non-singular covariance matrix. Taking the candidate of $\beta$ to be $b$, then the residual vector for $b$ will be $y-\boldsymbol{X} \boldsymbol{b}$. The generalized least squares method.

$$
\beta=a(y-\boldsymbol{X} \boldsymbol{b})^{T} \Psi^{-1}(y-\boldsymbol{X} \boldsymbol{b})
$$

For a quadratic form in $\boldsymbol{b}$, the estimator has an explicit formula:

$$
\beta=\left(\boldsymbol{X}^{T} \Psi^{-1} \boldsymbol{X}\right)^{-1} \boldsymbol{X}^{T} \Psi^{-1} \boldsymbol{y}
$$

Appealing properties of the GLS estimator is unbiased, consistency, efficiency, and asymptotically normal with $(\beta \mid X)$ $=\beta$, and $\left[\beta^{\top} \mid \boldsymbol{X}\right]=\left(\boldsymbol{X}^{T} \Psi^{-1} \boldsymbol{X}\right)^{-1}$. The estimate obtained with GLS is the best linear unbiased estimator (BLUE) for $\beta$.

\subsection{Feasible Generalized Least Squares (FGLS)}

To model FGLS, we start with OLS's model; it is considered an inefficient estimator. The residuals are utilized to build a constant estimator of the error covariance matrix. Next is to make use of the covariance matrix constant estimator's errors. Greene (2003) and Baltagi (2008) mentioned that for large samples, FGLS is preferred over OLS when a data set has heteroskedasticity or serial correlation. The FGLS is appreciated for large samples, but when samples are small, OLS should be used.

\subsection{Parameter Estimation of FGLS}

The ordinary least squares (OLS) estimator can be obtained by

$$
\beta_{O L S}=\left(\boldsymbol{X}^{\prime} \boldsymbol{X}\right)^{-1} \boldsymbol{X}^{\prime} \boldsymbol{y}
$$

And residual estimate $\hat{u_{j}}=\left(\boldsymbol{Y}-\boldsymbol{X} \beta_{O L S}\right)$

Assume that the covariance matrix variance $\Psi$ of the vector error is transverse so that each transverse threshold could fit residuals $\hat{u_{j}}$, and $\Psi_{o L s}$ may be obtained by

$$
\Psi_{O L S}=\left({\hat{\sigma_{1}}}^{2},{\hat{\sigma_{2}}}^{2}, \ldots,{\hat{\sigma_{n}}}^{2}\right)
$$

Once this step is completed, we can proceed as follows:

$$
\beta_{F G L S 1}=\left(\boldsymbol{X}^{\prime} \Psi^{-1} O L S \boldsymbol{X}\right)^{-1} \boldsymbol{X}^{\prime} \Psi^{-1}{ }_{O L S} \boldsymbol{y}
$$

The first iteration is given by

$$
\begin{gathered}
\hat{u F G L S 1}=\boldsymbol{Y}-\boldsymbol{X} \beta F G L S 1 \\
\Psi F G L S 1=(\hat{\sigma F G L S 2} \quad 1,1, \sigma F G L S 21,2, \ldots, \hat{\sigma} F G L S 21, n)
\end{gathered}
$$




$$
\Psi_{F G L S 2}=\left(\boldsymbol{X}^{\prime} \Psi_{F G L S 1}^{-1} \boldsymbol{X}\right)^{-1} \boldsymbol{X}^{\prime} \Psi_{F G L S 1}^{-1} \boldsymbol{y}
$$

The estimation of $\Omega$ can be iterated to convergence.

For any finite number of the iteration of FGLS estimator, it is asymptotically distributed as

$$
\sqrt{n}\left(\beta_{F G L S}-\beta\right) \rightarrow^{d}(0, \mathcal{C})
$$

Where $n$ is the sample point and $\mathcal{C}=p \lim \left(\boldsymbol{X}^{\prime} \Psi^{-1} \boldsymbol{X} \boldsymbol{T}\right)$ plim imply limit in probability. Software package by $\mathrm{R}$ core team (2019) was utilized for analyzing the data, and package "nlme" by Pinheiro, Bates, DebRoy \& Sarkar, (2018) was utilized for estimating the Generalized Least Square.

\subsection{Data Sources and Measurement}

The data was collected from the Human Development Index (HDR, 2017) and World Development Indicators (WDI, 2017). The variables are; Human Development Index (HDI), which represents economic welfare. The HDI factors utilized are adult literacy, life expectancy at birth, per capita gross domestic product, and school enrolment. Trade openness (TRDOPEN) is captured as the overall amount of import less the overall amount of export percentage of Gross Domestic Product (GDP); while, Foreign Direct Investment (FDI) is captured as FDI net inflow percentage of Gross Domestic Product (GDP). Domestic investments (DOMINV) is captured as gross fixed capital formation as a percentage of GDP; while, Infrastructure (INFR), is captured as electricity access percentage of the population. Labour (L) is captured as the active labour force percentage of the total population aged 15-64, and the rate of return on investment (ROI) is captured as the transpose of GDP Local Currency Unit (LCU) per capita.

\section{Results}

The feature of the variables in this study is examined through descriptive analysis. It gives a straightforward summary of the variables and their measures. This subsection indicates the correlation and the GLS estimate analysis of all variables in the study; HDI, TRDOPEN, FDI, DOMINV, INFR, L, and ROI on a sub-regional basis.

Table 1. Correlation coefficient of predictors for the Central sub-Saharan Region

\begin{tabular}{lllllll}
\hline & $($ Intr $)$ & FDI & $\log$ (DOMINV) & $\log$ (INFR) & $\log$ (TRDOPEN) & $\mathrm{L}$ \\
\hline FDI & 0.003 & & & & & \\
\hline $\log$ (DOMINV) & 0.355 & -0.418 & & & & \\
\hline $\log$ (INFR) & 0.160 & 0.101 & 0.203 & & & \\
\hline $\log$ (TRDOPEN) & -0.526 & -0.170 & -0.521 & -0.405 & & \\
\hline $\mathrm{L}$ & -0.909 & 0.102 & -0.279 & -0.007 & 0.256 & -0.736 \\
\hline $\log$ (ROI) & 0.848 & -0.206 & 0.613 & 0.337 & -0.387 & \\
\hline
\end{tabular}

Source: Authors (2019)

Table 2. GLS estimate for the Central sub-Saharan Region

\begin{tabular}{lllll}
\hline & Value & Std.Error & t-value & $\mathrm{p}$-value \\
\hline (Intercept) & -0.8688132 & 0.28218692 & -3.078857 & 0.0026 \\
\hline FDI & -0.0019071 & 0.00117674 & -1.620660 & 0.1076 \\
\hline $\log$ (DOMINV) & 0.0204342 & 0.03125357 & 0.653821 & 0.5144 \\
\hline $\log$ (INFR) & 0.1909262 & 0.01230058 & 15.521719 & 0.0000 \\
\hline $\log$ (TRDOPEN) & -0.0544386 & 0.02664052 & -2.043452 & 0.0431 \\
\hline $\mathrm{L}$ & -0.0076625 & 0.00182259 & -4.204172 & 0.0000 \\
\hline $\log$ (ROI) & -0.0103618 & 0.01323833 & -0.782712 & 0.4353 \\
\hline
\end{tabular}

Source: Authors (2019) 
The correlation coefficient for the Central sub-Saharan data is presented in Table 1. Using the Human Development Index (HDI) as the response variable, the generalized least square estimate presented in Table 2 shows that FDI, DOMINV, and ROI do not have a tangible impact on HDI. In contrast, TRDOPEN, INFR, and Labour have a significant relationship at a 0.05 significant level. Following the $t$-value in the fourth column, the predictor that impacts most on the response variable is INFR, followed by Labour, and then TRDOPEN. The Akaike Information Criteria (AIC) is -153.116, Bayesian Information Criteria (BIC) is -130.426 , and log-likehood is 84.5580.

The model for the Central sub-Saharan region becomes,

$H D I=-0.86881-0.0544386 * \log ($ TRDOPEN $)-0.00191 * F D I+0.02043 * \log ($ DOMINV $)+0.19093 * \log (I N F R)$ $-0.0076625 * \mathrm{~L}-0.0103618 * \log (R O I)$

Table 3. Correlation coefficient of predictors for the Eastern Sub-Saharan Region

\begin{tabular}{lllllll}
\hline & (Intr) & FDI & $\log ($ DOMINV) & $\log ($ INFR $)$ & $\log ($ TRDOPEN) & L \\
\hline FDI & 0.387 & & & & & \\
\hline $\log ($ DOMINV) & -0.333 & -0.475 & & & & \\
\hline $\log ($ INFR $)$ & 0.182 & 0.425 & -0.580 & & & \\
\hline $\log ($ TRDOPEN) & -0.747 & -0.548 & 0.396 & -0.646 & & \\
\hline L & -0.542 & 0.046 & -0.337 & 0.511 & 0.003 & $\underline{-0.396}$ \\
\hline$\underline{\log (\text { ROI })}$ & $\underline{0.582}$ & $\underline{-0.099}$ & $\underline{0.209}$ & $\underline{-0.056}$ & $\underline{-0.278}$ &
\end{tabular}

Source: Authors (2019)

Table 4. GLS estimate for the Eastern sub-Saharan Region

\begin{tabular}{lllll}
\hline & Value & Std.Error & t-value & p-value \\
\hline (Intercept) & -2.4576948 & 0.21260629 & -11.559841 & 0.0000 \\
\hline FDI & -0.0018407 & 0.00154643 & -1.190287 & 0.2357 \\
\hline $\log ($ DOMINV $)$ & -0.0637011 & 0.03074615 & -2.071839 & 0.0398 \\
\hline $\log ($ INFR $)$ & 0.2253518 & 0.01834196 & 12.286135 & 0.0000 \\
\hline $\log ($ TRDOPEN $)$ & 0.0925925 & 0.03474915 & 2.664598 & 0.0085 \\
\hline L & 0.0014937 & 0.00119628 & 1.248663 & 0.2136 \\
\hline $\log ($ ROI $)$ & -0.0645449 & 0.00547845 & -11.781600 & 0.0000 \\
\hline
\end{tabular}

Source: Authors (2019)

The correlation coefficient for the Eastern sub-Saharan data is presented in Table 3. Using the Human Development Index (HDI) as the response variable, the Generalized Least square estimate presented in Table 4 shows that FDI and Labour (L) do not have a tangible impact on HDI. In contrast, TRDOPEN, DOMINV, INFR, and ROI have a significant relationship with HDI at a 0.05 significant level. Following the $t$-value in the fourth column, the predictor that has the most impact on the response variable (HDI) is INFR, followed by ROI, TRDOPEN, and DOMINV. The Akaike Information Criteria (AIC) is -249.61 , Bayesian Information Criteria (BIC) is -224.81 , and log-likelihood is 132.80 .

The model for the Eastern sub-Saharan region becomes

$H D I=-2.45769+0.09260 * \log ($ TRDOPEN $)-0.00184 * F D I-0.02043 * \log (\mathrm{DOMINV})+0.22535 * \log (I N F R)+$ $0.00149 * \mathrm{~L}-0.06454 * \log (R O I)$ 
Table 5. Correlation coefficient of predictors for the Southern sub-Saharan Region

\begin{tabular}{lllllll}
\hline & \multicolumn{1}{c}{$($ Intr $)$} & FDI & $\log ($ DOMINV $)$ & $\log ($ INFR $)$ & $\log ($ TRDOPEN $)$ & $\mathrm{L}$ \\
\hline FDI & -0.025 & & & & & \\
\hline $\log ($ DOMINV $)$ & 0.392 & -0.179 & & & & \\
\hline $\log$ (INFR $)$ & 0.207 & 0.250 & 0.481 & & & \\
\hline $\log$ (TRDOPEN $)$ & -0.348 & 0.099 & 0.073 & 0.568 & & \\
\hline $\mathrm{L}$ & -0.792 & 0.008 & -0.786 & -0.426 & 0.032 & -0.708 \\
\hline $\log$ (ROI) & 0.572 & 0.110 & 0.623 & 0.888 & 0.436 & \\
\hline
\end{tabular}

Source: Authors (2019)

Table 6. GLS estimate for the Southern sub-Saharan Region

\begin{tabular}{lllll}
\hline & Value & Std.Error & t-value & p-value \\
\hline (Intercept) & -3.555082 & 0.10808903 & -32.89031 & 0.0000 \\
\hline FDI & 0.000676 & 0.00113852 & 0.59415 & 0.5539 \\
\hline $\log ($ DOMINV $)$ & 0.047657 & 0.01641871 & 2.90263 & 0.0047 \\
\hline $\log ($ TRDOPEN $)$ & -0.034607 & 0.01900548 & 0.83826 & 0.4042 \\
\hline L & 0.009352 & 0.00083130 & -2.85719 & 0.0053 \\
\hline $\log ($ ROI $)$ & -0.230835 & 0.01418373 & -16.27460 & 0.0000 \\
\hline
\end{tabular}

Source: Authors (2019)

The correlation coefficient for the Southern sub-Saharan data is presented in Table 5. Using the Human Development Index (HDI) as the response variable, the Generalized Least square estimate presented in Table 6 shows that FDI and INFR do not have a tangible impact on HDI. In contrast, TRDOPEN, DOMINV, L, and ROI have a significant relationship with HDI at a 0.05 significant level. Following the t-value in the fourth column, the predictor that has the most impact on the response variable (HDI) is ROI, followed by Labour (L), DOMINV, and TRDOPEN. The Akaike Information Criteria (AIC) is -351.589, Bayesian Information Criteria (BIC) is -331.771, and log-likelihood is 183.795 .

The model for the Southern sub-Saharan region becomes

$$
H D I=-3.5551-0.03461 * \log (\mathrm{TRDOPEN})+0.00068 * F D I+0.04766 * \log (\mathrm{DOMINV})+0.01593 * \log (I N F R)+
$$
$0.00935 * \mathrm{~L}-0.2308 * \log (R O I)$

Table 7. Correlation coefficient of predictors for the Western sub-Saharan Region

\begin{tabular}{|c|c|c|c|c|c|c|}
\hline FDI & (Intr) 0.058 & FDI & $\underline{\log (\text { DOMINV) }}$ & $\underline{\log (\text { INFR })}$ & $\log$ (TRDOPEN) & $\mathrm{L}$ \\
\hline $\log (\mathrm{DOMINV})$ & -0.155 & -0.264 & & & & \\
\hline $\log (\mathrm{INFR})$ & -0.543 & 0.091 & 0.213 & & & \\
\hline $\log$ (TRDOPEN) & -0.535 & -0.330 & -0.298 & -0.120 & & \\
\hline $\mathrm{L}$ & -0.442 & 0.269 & -0.004 & 0.071 & -0.104 & \\
\hline $\log (\mathrm{ROI})$ & 0.602 & -0.279 & 0.146 & -0.360 & -0.083 & -0.369 \\
\hline
\end{tabular}

Source: Authors (2019) 
Table 8. GLS estimate for the Western sub-Saharan Region

\begin{tabular}{lllll}
\hline & Value & Std.Error & t-value & p-value \\
\hline (Intercept) & -1.6899618 & 0.12627618 & -13.383061 & 0.0000 \\
\hline FDI & 0.0044637 & 0.00145731 & 3.062939 & 0.0026 \\
\hline $\log ($ DOMINV) & 0.0886621 & 0.01426053 & 6.217310 & 0.0000 \\
\hline $\log ($ INFR $)$ & 0.2476612 & 0.01475210 & 16.788201 & 0.0000 \\
\hline $\log ($ TRDOPEN) & -0.0637299 & 0.02129645 & -2.992514 & 0.0032 \\
\hline L & 0.0013317 & 0.00074353 & 1.791033 & 0.0751 \\
\hline $\log ($ ROI $)$ & 0.0103377 & 0.00306986 & 3.367495 & 0.0009 \\
\hline
\end{tabular}

Source: Authors (2019)

The correlation coefficient for Western sub-Saharan data is presented in Table 7. Using the Human Development Index (HDI) as the response variable, the generalized least square estimate presented in Table 8, all the variables have a significant relationship with HDI at 0.05 significant level except Labour (L). Following the t-value in the fourth column, the predictor that has the most impact on the response variable (HDI) is INFR, followed by DOMINV, ROI, FDI, and TRDOPEN. The Akaike Information Criteria (AIC) is -332.109 , Bayesian Information Criteria (BIC) is -307.303, and log-likelihood is 174.05 .

The model for the Western sub-Saharan region becomes

$$
\begin{gathered}
H D I=-1.68996-0.06373 * \log (\text { TRDOPEN })+0.00446 * F D I+0.08866 * \log (\mathrm{DOMINV})+0.24766 * \log (I N F R) \\
+0.00133 * \mathrm{~L}+0.01033 * \log (\text { ROI })
\end{gathered}
$$

\section{Discussions}

This study investigated the impact of trade openness, foreign direct investment, and economic welfare on a sub-Saharan African regional analysis. The impact of openness to trade and the net inflow of foreign direct investment have been ascertained on economic welfare for selected countries in the region. The generalized least square method was adopted in this study. The technique is considered suitable, and the results presented in Tables 1, 3, 5, and 7 shows a significant correlation among the predictors. The models estimated result reveals that trade openness is significant on economic welfare in all sub-region of the sub-Saharan African region. However, foreign direct investment is significant on economic welfare only in the Western sub-region. FDI was not significant in the Central, Eastern, and Southern sub-regions, as highlighted in equation (2), which is emphasized in Tables 2, 4, 6, and 8.

From the analysis and results, the study construed that trade openness has a tangible impact relative to the level of welfare economically for all regions of sub-Saharan Africa. It agrees with the study by (Falvey, Foster, \& Greenaway, 2012, Salinas, Gueye, \& Korbut, 2014, Wacziarg \& Welch, 2008). However, FDI has a tangible impact on economic welfare only in the Western region of sub-Saharan Africa, probably because of lower dependence on foreign capital flows. This could have resulted in greater growth and enhanced welfare (Prasad et al., 2007; Carbonell and Werner, 2018). The Western regions were probably encouraged to maximally engage their domestic investment to reduce possible incidences of displacement of domestic competitors (Szkorupova 2015). As evidenced in the research work on Central and Eastern Europe, the crowding-out effect is real, showing undue influence by the foreign investors, hence, disallowing the domestic investors to thrive nor engage gainfully sufficiently to result in a tangible enhancement of the domestic investment sectors of the countries.

This is not farfetched as the more developing economies depend on foreign investment, the more their domestic investment remains inactive, passive, and undeveloped (Adegboye 2014). As seen for all regions in sub-Saharan Africa, trade openness does seek to enhance productivity and economic activities in the domestic market, which would invariably result in an increase in income and, hence, investment for the developing host economies (Prasad, Rajan \& Subramanian 2007). These regions' likely condition is to enhance trade liberalization with sufficient room for increased economic activities to thrive, thereby bringing about desired economic welfare as income grows. These are reinforced with enhanced education, improved skill development, and better health provisions sustainably, bringing about better living standards (Osabuohien, Efobi, \& Gitau 2015). 
It shows that the foreign capital inflow was not isolated to act in response solely to investment opportunities for the selected countries. Thus, trade openness with the promise of thriving economic activities would proffer quantifiably enhance domestic savings, therefore investing in these regions. It could be achieved in the manner that growth in income in the domestic economy would be gradually enhanced to the level where dependence on foreign capital would decline over the years (Long, Stretesky, \& Lynch 2017). These are in agreement with the anticipation of the standard economic theories, as trade openness and foreign assistance is required in the host economy to supplement the lack of domestic capital, and investments. Thereby, increasing productivity, economic activities, to augment the dearth of domestic investment, hence, bringing about economic growth and welfare (Adegboye 2014).

Having identified the suitability of GLS in fitting the data relative to OLS, the study by (Musau et al. 2015) established that Feasible Generalized Least Square (FGLS) was a good fit for their data. This may not be true for all types of data set. Therefore, future work may consider fitting panel data with generalized (GLS) and Feasible Generalized Least Square (FGLS), described in this study, and draw a comparison between the two techniques.

\subsection{Conclusion and Recommendations}

In conclusion, the study submits that for sub-Saharan Africa, though openness to trade has produced outcomes of economic growth and better living standard, the inflow of foreign assistance has not thrived in enhancing economic welfare. Rather, it could be seen that the welfare enhancement produced by trade openness activities are neither tangibly sufficient nor sustainable. The research work recommends that the government of selected countries in the sub-Saharan Africa region should encourage trade openness to improve productivity and enhanced economic activities in order to engender industrial development. However, the inflow of foreign finance should be executed with the flows focused on essential sectors. This would improve the proficiency and network of domestic firms to facilitate the effective performance of the domestic sector. These achievements would improve trade activities, better incomes, and enhanced positions in the trade balance. This would convey substantially improved results for sustainable growth, hence, desired economic welfare.

\section{Acknowledgements}

We acknowledge the research articles cited and reviewed in the course of this research work. Our acknowledgement goes to Covenant University Centre for Research, Innovation, and Development (CUCRID) for the research publication funding.

\section{References}

Adegboye, F. B. (2014). Foreign direct investment and economic development: evidence from selected African countries. Ph.D Thesis, Covenant University, Ota. https://doi.org/10.5171/2015.875171

Adegboye, F. B., Odularu, G., \& Matthew, O. A. (2020). The US-China trade war: what is Africa's Gain. In G. Odularu, M. Hassan, \& M. Babatunde (Eds.), Fostering trade in Africa (pp. 153-170). Advances in African Economic, Social and Political Development. Springer, Cham. https://doi.org/10.1007/978-3-030-36632-2_7

Adegboye, F. B., Ojo, J. A. T., \& Ogunrinola, I. I. (2016). Foreign direct investment and industrial performance in Africa. The Social Sciences, 11(24), 5830-5837.

Aitken, A. C. (1934). On least-squares and linear combinations of observations. Proceedings of the Royal Society of Edinburgh, 55, 42-48. https://doi.org/10.1017/S0370164600014346

Alfaro, L., \& Chauvin, J. (2018). Foreign direct investment, finance, and economic development. In M. Spatareanu (Ed.), Encyclopedia of international economics and global trade: Foreign direct investment and the multinational enterprise. Singapore: World Scientific, forthcoming.

Ali, N., \& Xialing, L. (2017). Foreign direct investment, international trade, and economic growth in Pakistan's economic perspective. American Journal of Economics, 7(5), 211-215. https://doi.org/10.5923/j.economics.20170705.02

Amoo, E. O. (2018). Introduction to special edition on covenant university's perspectives on Nigeria Demography and Achievement of SDGs-2030. African Population Studies, 32(1), 3993-3996.

Baltagi, B. H. (2008). Econometrics (4th ed.). New York: Springer.

Bluestone, B., \& Harrison, B. (2000). Growing prosperity: The battle for growth with equity in the 21st Century. New York, the Centurion Foundation.

Brueckner, M., \& Lederman, D. (2015). Effect of income inequality on aggregate output. World Bank Policy Research Working Paper No7317. Retrieved from https://papers.ssrn.com/sol3/papers.cfm?abstract_id=2621871\#\# 
Buckley, P. J. (2010). Stephen hymer: three phases, one approach?. In Foreign Direct Investment, China, and the World Economy. Palgrave Macmillan, London. https://doi.org/10.1057/9780230248328_3

Carbonell, J. B., \& Werner, R. A. (2018). Does foreign direct investment generate growth? A new empirical approach applied to Spain. Economic Geography, 94(4), 425-456. https://doi.org/10.1080/00130095.2017.1393312

Chenery, H. B., \& Strout, A. (1966). Foreign assistance and economic development. American Economic Review, 55, 679-733.

Core Team. (2019). A language and environment for statistical computing. Foundation for Statistical Computing, Vienna, Austria. Retrieved from https://www.R-project.org/

Du, Q., \& Kang, J. T. (2016). Tentative ideas on the reform of exercising state ownership of natural resources: preliminary thoughts on establishing a state-owned natural resources supervision and administration commission. Jiangxi Social Science, 6, 160.

Eozenou, P. (2008). Financial integration and macroeconomic volatility: Does financial development matter?. Working Paper, European University Institute.

Falvey, R., Foster, N., \& Greenaway, D. (2012). Trade liberalization, economic crises, and growth. World Development, 40(11), 2177-2193. https://doi.org/10.1016/j.worlddev.2012.03.020

Geda, A., \& Seid, E. H. (2015). The potential for internal trade and regional integration in Africa. Journal of African Trade, 2, 19-50. https://doi.org/10.1016/j. joat.2015.04.001

Greene, W. H. (2003). Econometric Analysis (5th ed.). Upper Saddle River, NJ: Prentice Hall.

Human Development Reports. (2017). United Nations development programme. Retrieved from https://hdr.undp.org/en/data\#

Hymer, S. H. (1976). The international operations of national firms: a study of direct investment. MIT Press, Mass. Cambridge.

Ikpesu, F., Vincent, O., \& Dakare, O. (2019). Growth effect of trade and investment in Sub-Saharan Africa countries: Empirical insight from panel corrected standard error (PCSE) technique. Cogent Economics \& Finance, 7 , 1607127. https://doi.org/10.1080/23322039.2019.1607127

Long, M. A., Stretesky, P. B., \& Lynch, M. J. (2017). Foreign direct investment, ecological withdrawals, and natural-resource-dependent economies. Society \& Natural Resources, 1261-1276. https://doi.org/10.1080/08941920.2017.1331483

Lumengo, B., \& Emilie, K. (2019). The growth effect of trade openness on African countries: evidence from using an instrumental variable panel smooth transition model. MPRA Paper 92111, University Library of Munich, Germany.

Matthew, O., \& Adegboye, F. B. (2014). Trade Openness, Institutional and Economic Growth in sub-Saharan Africa (SSA). Developing Country Studies, 4(8), 18-30.

Mensah, J. (2019). Sandra Ricart Casadevall (Reviewing editor). Sustainable development: Meaning, history, principles, pillars, and implications for human action: Literature review. Cogent Social Sciences, 5(1). https://doi.org/10.1080/23311886.2019.1653531

Musau, V. M., Waititu, A. G., \& Wanjoya, A. K. (2015). Modeling panel data: comparison of gls estimation and robust covariance matrix estimation. American Journal of Theoretical and Applied Statistics, 4(3), 185-191. https://doi.org/10.11648/j.ajtas.20150403.25

Osabuohien, E. S., \& Efobi, U. R. (2014). Assessment of trade performance of OIC African members in the face of global economic crisis. Journal of Economic Cooperation and Development, 35(1), 1-22.

Osabuohien, E. S., Efobi, U. R., \& Gitau, C. M. (2015). Environmental challenges in Africa further dimensions to the trade, MNCs, and energy debate. Management Environmental Quality, an International Journal, 26(1), 118-137. https://doi.org/10.1108/MEQ-04-2014-0058

Pinheiro, J., Bates, D., DebRoy, S., \& Sarkar, D. R. (2018). Nlme: linear and nonlinear mixed effects models. $R$ Package Version, 3, 1-137. Retrieved from https://CRAN.R-project.org/package=nlme

Prasad, E. S., Rogoff, K., Wei, S., \& Kose, M. A. (2003). The effects of financial globalization on developing countries: some empirical evidence. IMF Occasional Paper 220, Washington. 
Prasad, E., Rajan, R., \& Subramanian, A. (2007). The paradox of capital. Financial Globalization, Finance \& Development, 44(1).

Rao, B. B., Tamazian, A., Singh, R., \& Vadlamannati, K. C. (2008). Financial growth and the rate of growth of output: an alternative approach. MPRA Paper No. 8605. Retrieved from http://mpra.ub.uni-muenchen.de/8605/

Salinas, G., Gueye, C., \& Korbut, O. (2014). Impressive growth in Africa under peace and market reforms. Journal of African Economies, 24(1), 101-127. https://doi.org/10.1093/jae/eju025

Szkorupova, Z. (2015). Relationship between foreign direct investment and domestic investment in selected countries of central and Eastern Europe. Prodecia Economics and Finance, 23, 1017-1022. https://doi.org/10.1016/S2212-5671(15)00350-0

Turner, R. K. (1988). Sustainable environmental development principles and practice. London: Belhaven Press.

United Nations Center for Trade and Development. (2012). UNCTADstat; Economic Indicators. Extracted from IMF Data Warehouse.

United Nations Center for Trade and Development. (2018). World Investment Report: Investment and New Industrial Policies. United Nations Publication, Geneva. Retrieved from https://unctad.org/en/PublicationsLibrary/wir2018_en.pdf

United Nations. (2020). Sustainable development goals. Department of Economic and Social Affairs Disability. Retrieved from https://www.un.org/development/desa/disabilities/ envision2030.html

Wacziarg, R., \& Welch, K. H. (2008). Trade liberalization and growth: new evidence. The World Bank Economic Review, 22(2), 187-231. https://doi.org/10.1093/wber/lhn007

Winters, L. A., \& Masters, A. (2013). Openness and growth: still an open question?. Journal of International Development, 25(8), 1061-1070. https://doi.org/10.1002/jid.v25.8

Workneh, M. A., \& Francken, N. (2015). The review of the impact of aid on domestic saving. Munich Personal RePEc Archive. MPRA Paper No 92174. Retrieved from https://mpra.ub.unimuenchen.de/92174/

World Commission Environment and Development. (1987). Our common future. Oxford University Press.

World Development Indicators. (2017). The World Bank. Retrieved from https://datacatalog.worldbank.org/dataset/world-development-indicators

Zahonogo, P. (2016). Trade and economic growth in developing countries: evidence from Sub-Saharan Africa. Journal of African Trade, 3(1-2), 41-56. https://doi.org/10.1016/j.joat.2017.02.001

\section{Copyrights}

Copyright for this article is retained by the author(s), with first publication rights granted to the journal.

This is an open-access article distributed under the terms and conditions of the Creative Commons Attribution license (http://creativecommons.org/licenses/by/4.0/). 